\title{
IMPLEMENTASI RENCANA PROGRAM PEMBELAJARAN BERBASIS KOMPETENSI PADA PEMBELAJARAN KOMPETENSI DASAR MENULIS PROGRAM CNC
}

\author{
Y a y a $\mathbf{t}^{1}$
}

\begin{abstract}
Abstrak : Penelitian ini bertujuan untuk menganalisis dan mengambarkan tingkat penguasaan siswa terhadap kompetensi dasar menulis program CNC melalui implementasi Rencana Program Pembelajaran (RPP) berbasis kompetensi dengan aspek kognitif level pemahaman, aspek psikomotor level respon terbimbing, dan aspek apektif level merespon. Jumlah anggota sampel dalam penelitian ini sebanyak 33 orang siswa. Penelitian dilakukan dengan menggunakan metode penelitian quasi experiment. Data dianalisis secara deskriptif dengan menggunakan nilai rata-rata, standar deviasi, persentase, dan Normalized N-gain. Hasil penelitian menunjukkan bahwa tingkat penguasaan siswa terhadap kompetensi dasar menulis program CNC melalui implementasi RPP berbasis komptensi tergolong katagori cukup. Adapun untuk setiap aspeknya baik untuk aspek kognitif, aspek psikomotor, dan aspek apektif juga tergolong kedalam kategori sedang.
\end{abstract}

\begin{abstract}
This research aimed to analyze and describe the mastery of the vocational high school student's to basic competencies in writing CNC programs through the implementation of competence-based lesson plans, with the cognitive aspect at understanding level, the psychomotor aspect at guided instruction level, and affective aspect at responding level. The number of samples in this study are 33 students. Research carried out by using the method of quasi experiment research The data was analyzed using means, deviation standard, percentage, and Normalized N-gain. The results showed that the mastery of the vocational high school student's for basic competencies in writing CNC programs through the implementation of competence-based lesson plans classified as enough category. As for every aspect for cognitive, psychomotor, and affective aspects are also classified into medium category.
\end{abstract}

Kata kunci: Rencana Program Pembelajaran, kompetensi, dan CNC

\section{PENDAHULUAN}

Digunakannya teknologi Computer Numerically Controlled (CNC) dalam industri manufaktur, menuntut tersedianya Sumber Daya Manusia (SDM) yang kompeten dalam bidang tersebut. Kondisi tersebut akan berimbas terhadap keberadaan lembaga pendidikan yang menyiapkan caloncalon tenaga kerja, seperti lembaga pendidikan menengah kejuruan yang lebih dikenal dengan nama Sekolah Menengah Kejuruan (SMK). Sebagaimana ditegaskan dalam Penjelasan UU Sisdiknas No. 20 Tahun 2003 Pasal 15, SMK merupakan pendidikan menengah yang mempersiapkan peserta didik terutama untuk bekerja dalam bidang tertentu. SMK menyiapkan peserta didik menjadi manusia produktif yang dapat langsung bekerja di bidangnya, setelah melalui pendidikan dan pelatihan (diklat) berbasis kompetensi.

SMK menyelenggarakan diklat berbagai program keahlian yang disesuaikan dengan kebutuhan dunia industri, serta menyajikan materi dalam bentuk berbagai kompetensi kejuruan yang dibutuhkan untuk menjadi tenaga kerja yang kompeten sesuai dengan Standar Kompetensi Kerja Nasional Indonesia (SKKNI) yang ditetapkan oleh dunia industri. Standar ini menyangkut standar kompetensi peserta didik dengan aturan go dan no go, sehingga diperlukan proses pembelajaran untuk menghasilkan lulusan SMK yang kompeten sebagaimana diharapkan oleh dunia industri. Pada proses pembelajaran, peserta didik mengikuti program diklat dengan acuan kurikulum.

Salah satu program keahlian yang ada

di SMK adalah program keahlian Teknik 
Mesin dengan kompetensi keahlian Teknik Pemesinan. Alumni Sekolah Menengah Kejuruan (SMK) program studi keahlian teknik mesin dengan kompetensi keahlian teknik pemesinan, dituntut untuk menguasai sejumlah kompetensi yang terkait dengan operasi mesin, yang salah satunya adalah kompetensi dalam mengoperasikan mesin CNC. Untuk dapat mengoperasikan mesin CNC, diperlukan sejumlah perintah yang dikenal dengan istilah program (program CNC). Dengan demikian, seseorang yang akan bekerja dengan mesin CNC, maka orang tersebut harus memiliki kompetensi dalam menulis program (program CNC). Sekaitan dengan itu, program keahlian ini menyelenggarakan mata pelajaran Computer Numerically Controlled (CNC), yaitu salah satu mata pelajaran bidang otomasi yang harus dikuasai oleh peserta didik. Seiring dengan penerapan otomasi di sektor industri yang mengalami perkembangan pesat, peserta didik dituntut untuk memiliki kompetensi kerja otomasi menggunakan CNC sesuai Kurikulum SMK, sehingga dapat menjadi tenaga kerja yang mampu bersaing di industri global. Dengan kata lain, agar para lulusan SMK dapat menguasai kompetensi dalam mengoperasikan mesin CNC, maka mereka harus menguasai beberapa kompetensi yang terkait dengan operasi mesin CNC, dan salah satunya adalah menulis program $\mathrm{CNC}$.

Dalam mewujudkan harapan tersebut, yakni membekali para lulusan SMK dengan sejumlah kompetensi yang dituntut oleh Dunia Usaha/Industri (DUDI), khususnya terkait operasi mesin CNC, bukanlah merupakan pekerjaan yang mudah. Oleh karena, kenyataan di lapangan masih ditemui sejumlah masalah penting yang terkait dengan pelaksanaan pembelajaran mata pelajaran CNC. Permasalahan-permasalahan tersebut diantaranya adalah: a) kemampuan guru dalam mengembangkan RPP yang memenuhi prinsip pembelajaran kurikulum berbasis kompetensi, b) karakteristik siswa dengan latar belakang pendidikan yang berbeda, c) jumlah peralatan yang terbatas, dan d) kemampuan guru dalam mengelola
PBM. Dengan dihadapkannya pada permasalahan tersebut, tidak mengherankan apabila hasil pembelajaran yang dicapai oleh siswapun belum cukup memuaskan. Oleh karena berdasarkan data dari salah satu SMK Negeri di Kota Bandung, setelah dilakukan uji kompetensi pada mata pelajaran CNC, ternyata belum ada satu orang siswapun yang mampu meraih nilai dengan kualifikasi A, melainkan hanya pada kualifikasi B dan C.

Apabila melihat hasil uji kompetensi tersebut, maka peserta didik memerlukan pengembangan dalam pencapaian kompetensi, karena prestasi belajar peserta didik merupakan tingkat keberhasilan dari hasil pembelajaran. Hasil belajar yang diperoleh siswa merupakan refleksi dari kualitas pembelajaran yang dilaksanakan. Dalam proses pembelajaran, guru merupakan komponen system pendidikan formal yang langsung berhubungan dengan peserta didik. Keberhasilan proses belajar mengajar dalam mencapai tujuan pembelajaran sangat ditentukan oleh guru. Sehubungan dengan itu, guru harus mampu melakukan tugasnya secara professional. Seorang guru dikatakan professional apabila dia mampu mengelola pembalajaran secara efektif. Dengan kata lain, guru professional dapat dikatakan sebagai guru yang efektif. Mengenai guru yang efektif, Gary A. Davis dan Margaret A. Thomas yang dikutif oleh Suyanto (2007) menjelaskan bahwa guru dikatakan efektif apabila memiliki cirri-ciri sebagai berikut: 1) memiliki kemampuan yang terkait dengan iklim belajar di kelas, 2) memiliki kemampuan yang terkait dengan strategi manajemen pembelajaran, 3) memiliki kemampuan yang terkait dengan pemberian umpan balik (feedback) dan penguatan (reinforcement), dan 4) memiliki kemampuan yang terkait dengan peningkatan diri.

Terkait dengan ciri-ciri di atas, jelaslah bahwa guru harus mampu mengelola pembelajaran dengan baik. Pengelolaan pembelajaran yang baik akan mewujudkan kualitas pembelajaran yang baik, yang pada gilirannya akan meningkatkan kualitas hasil pembelajaran. 
Kualitas hasil pembelajaran yang baik ditunjukkan dengan baiknya tingkat penguasaan peserta didik terhadap suatu kompetensi. Dengan kata lain, agar para siswa dapat mengusai tuntutan kompetensi yang disyaratkan, sudah menjadi keharusan proses pembelajarannya dikelola dengan baik. Oleh karena, proses pembelajaran pada hakekatnya merupakan implementasi dari suatu kurikulum.

Kualitas pembelajaran ini berawal dari RPP yang didesain oleh guru, yang merupakan pedoman bagi guru yang bersangkutan untuk mencapai tuntutan suatu kompetensi dalam proses pembelajaran. RPP yang representatif diprediksi akan memperlancar proses pembelajaran, sehingga peserta didik dapat mencapai tuntutan kompetensi yang dipelajarinya secara tuntas. Dengan dibuatnya RPP tersebut, paling tidak: (1) arah dalam usaha-usaha pengajaran menjadi jelas; (2) dapat diketahui apakah tujuan tersebut telah dicapai atau belum; (3) dapat diidentifikasi hambatan-hamabatan yang mungkin timbul dalam pelaksanaannya, dan (4) dapat dihindari dari pertumbuhan dan perkembangan yang diluar perencanaan/tujuan. Sesuai dengan kurikulum yang digunakan, yaitu kurikulum berbasis kompetensi, maka RPP pun harus RPP yang dapat memandu guru pada saat pembelajaran yang mengarah pada upaya pencapaian suatu kompetensi.

Mengacu pada permasalahan seperti yang telah dipaparkan sebelumnya, peneliti merumuskan permasalahan dalam penelitian ini adalah "Bagaimana penguasaan siswa terhadap kompetensi dasar menulis program CNC dengan implementasi RPP berbasis kompetensi?” Dari rumusan masalah pokok tersebut, peneliti mencoba menguraikan kembali ke dalam beberapa pertanyaan penelitian sebagai berikut:

a. Bagaimana penguasaan siswa terhadap kompetensi menulis program CNC pada aspek kognitif?

b. Bagaimana penguasaan siswa terhadap kompetensi menulis program CNC pada aspek psikomotor? c. Bagaimana penguasan siswa terhadap kompetensi menulis program CNC pada aspek afektif?

Berdasarkan permasalahan tersebut, maka tujuan yang ingin dicapai dari penelitian ini secara umum adalah untuk mendapatkan gambaran aktual tentang penguasaan siswa SMK program keahlian teknik pemesinan terhadap kompetensi dasar menulis program CNC. Adapun secara khusus, tujuan dari penelitian ini bertujuan untuk mendapatkan gambaran aktual mengenai: a) hasil belajar siswa pada pembelajaran kompetensi dasar menulis program NC/CNC dengan aspek kognitif level pemahaman, psikomotor level respon terbimbing dan apektif level merespon melalui implementasi RPP berbasis kompetensi, dan b) pengaruh implementasi RPP berbasis kompetensi terhadap hasil belajar siswa pada pembelajaran kompetensi dasar menulis program NC/CNC.

Hasil penelitian ini akan bermanfaat dalam meningkatkan efektivitas, efesiensi, dan akuntabilitas pelaksanaan pembelajaran pada kompetensi dasar menulis program CNC. Secara khusus, hasil penelitian ini memberikan kontribusi yang signifikan bagi: a) SMK guna lebih mengoptimalkan perannya sebagai bagian dari lembaga pendidikan menengah kejuruan yang menghasilkan calon tenaga kerja untuk mengisi kekosongan tenaga kerja di indusrti, khususnya industri permesinan, dan b) guru sebagai pelaksana kurikulum di lapangan dalam mengembangkan desain pembelajaran (RPP) yang dapat digunakan sebagai panduan dalam pelaksanaan pembelajaran.

\section{LANDASAN TEORI}

Perencanaan pengajaran merupakan langkah utama yang penting, yang harus dilakukan oleh guru. Dengan dibuatkannya perencanaan pengajaran, paling tidak: (1) arah dalam usaha-usaha pengajaran menjadi jelas; (2) dapat diketahui apakah tujuan tersebut telah dicapai atau belum; (3) dapat diidentifikasi hambatan-hamabatan yang mungkin timbul dalam pelaksanaannya, dan (4) dapat dihindari dari pertumbuhan dan 
perkembangan yang diluar perencanaan/tujuan.

RPP adalah suatu pedoman bagi guru dalam melaksanakan kegiatan pembelajaran, sehingga dapat membantu proses belajar peserta didik dalam mencapai kompetensi secara optimal. RPP yang disusun harus mengacu pada prinsip pembelajaran kurikulum berbasis kompetensi sebagai berikut (Prisma Sanjaya, 2005):

1. Tujuan pembelajaran jelas.

2. Pembelajaran berfokus pada peserta didik (student centered).

3. Menekankan pada penguasaan kompetensi.

4. Menekankan pada pencapaian performansi.

5. Menggunakan strategi pembelajaran yang dapat mengakomodasi cara belajar yang bervariasi.

6. Menggunakan metode pembelajaran yang bersifat learning by doing.

7. Pembelajaran bersifat individual (individualized learning) dilakukan dengan menggunakan modul.

8. Memperhatikan kebutuhan dan kecepatan belajar peserta didik secara individu.

9. Media dan materi yang digunakan didesain untuk membantu pencapaian kompetensi.

10. Kegiatan pembelajaran hendaknya memperhatikan kemudahan proses pemonitoran untuk memudahkan pengaturan program belajar.

11. Kegiatan pembelajaran diadministrasikan.

12. Memanfaatkan sumber daya internal dan eksternal sekolah.

13. Pembelajaran dapat dilakukan di sekolah dan di luar sekolah.

14. Lingkungan belajar dikondisikan seperti dunia kerja.

15. Melakukan penilaian hasil belajar untuk mendapatkan umpan balik.

16. Penilaian dilakukan terhadap performansi yang dicapai dengan cara demonstrasi.

17. Tingkat performansi peserta diklat ditentukan dengan membandingkan kriteria unjuk kerja dengan kompetensi yang akan dicapai.

RPP yang dikembangkan oleh setiap sekolah harus dapat menjadi pedoman bagi guru dalam melaksanakan kegiatan pembelajaran, sehingga peserta didik menguasai secara tuntas tahap demi tahap kompetensi yang sedang dipelajari. Dalam mengembangkan RPP dalam konteks pembelajaran berbasis kompetensi, harus ditetapkan dulu secara ajeg tentang konsep kompetensi. Mulyasa (2003: 37) mengemukakan bahwa "kompetensi adalah perpaduan dari pengetahuan, keterampilan, nilai dan sikap yang direfleksikan dalam kebiasaan berpikir dan bertindak". Sementara, Mc. Ahsan (Mulyasa, 2003: 38) mengartikan kompetensi sebagai:"pengetahuan, keterampilan, dan kemampuan yang telah dikuasai seseorang yang telah menjadi bagian dari dirinya, sehingga dapat melakukan perilaku-perilaku kognitif, afektif, dan psikomotor dengan sebaik-baiknya." Sejalan dengan itu, Finch dan Crunkilton (Mulyasa, 2003: 38) mengemukakan bahwa 'kompetensi merupakan penguasaan terhadap suatu tugas, keterampilan, sikap, dan apresiasi yang diperlukan untuk menunjang keberhasilan'.

Konsep Kompetensi menurut Majelis

Pendidikan Kejuruan Nasional (1999) diartikan sebagai suatu kemampuan yang didasari oleh pengetahuan (knowledge/ranah kognitif), keterampilan (skill/ranah psikomotor), dan didukung oleh sikap kerja (aptitude/ranah afektif) serta penerapannya dalam melaksanakan suatu tugas/pekerjaan di tempat kerja dengan mengacu pada kriteria unjuk kerja yang dipersyaratkan. Kompetensi juga dapat diartikan sebagai kemampuan melaksanakan tugas yang diperoleh melalui pendidikan dan pelatihan, yang mencakup aspek pengetahuan, keterampilan, dan sikap.

Berdasarkan sumber lain, yakni dari Pusat Kurikulum, Balitbang Depdiknas (2002); Kompetensi merupakan pengetahuan, keterampilan, dan nilai-nilai dasar yang direfleksikan dalam kebiasaan berpikir dan bertindak. Kebiasaan berpikir dan bertindak 
secara konsisten dan terus-menerus memungkinkan seseorang menjadi kompeten, dalam arti memiliki pengetahuan, keterampilan, dan nilai-nilai dasar untuk melakukan sesuatu. Dengan demikian, jelaslah bahwa yang dimaksud dengan seseorang dikatakan kompeten dalam suatu bidang (mata pelajaran) yakni yang memiliki pengetahuan, keterampilan, dan nilai/sikap secara terintegrasi, secara proporsional, yakni sesuai dengan level atau tingkatan kompetensi yang dimaksud. Artinya, untuk setiap ranah yang membentuk kompetensi (kognitif, afektif, dan psikomotor) tuntutannya harus dikuasai secara tuntas (mastery). Hal inilah yang menjadi tantangan positif bagi setiap guru dalam menterjemahkan/ mengejewantahkan tuntutan Kurikulum Berbasis Kompetensi. Sekaitan dengan itu, para guru dituntut untuk mampu merancang pembelajaran berdasarkan tuntutan kompetensi, baik untuk ranah kognitif, ranah afektif maupun ranah psikomotornya secara proporsional. Berdasarkan beberapa pendapat di atas, maka yang dimaksud dengan kompetensi pada penelitian ini adalah kemampuan pengetahuan, keterampilan, dan sikap yang harus dikuasai peserta didik setelah menyelesaikan proses pembelajaran pada kompetensi dasar menulis program CNC.

Kompetensi mengandung beberapa aspek yang termasuk ke dalam taksonomi tujuan pengajaran, yaitu suatu kategorisasi tujuan pendidikan yang umumnya digunakan sebagai dasar dalam merumuskan tujuan kurikulum dan tujuan pembelajaran. Taksonomi tujuan pembelajaran terdiri dari aspek kognitif, psikomotor, dan afektif. Kognitif menitikberatkan pada proses intelektual. Psikomotor merupakan kategori tujuan pendidikan yang menunjuk pada gerakan-gerakan jasmaniah yang berupa pola-pola gerakan atau keterampilan fisik yang khusus/urutan keterampilan. Adapun afektif merupakan aspek-aspek penting dalam perkembangan peserta didik yang meliputi sikap, perasaan, emosi, dan karakterisasi moral.
Di SMK, kompetensi dasar menulis program CNC merupakan salah satu kompetensi dasar dari standar kompetensi Memprogram Mesin NC/CNC dengan kode kompetensi M7.18A. Berikut ini adalah beberapa Standar Kompetensi yang berhubungan dengan operasi mesin CNC berdasarkan Standar Kompetensi Kerja Nasional Indonesia (SKKNI), yaitu: 1) Standar Kompetensi Mengoperasikan Mesin NC/CNC (M7.28A), b) Standar Kompetensi Memprogram Mesin NC/CNC (M7.18A), c) Standar Kompetensi Mengeset dan Mengedit program mesin NC/CNC (M7.16A), dan d) Standar Kompetensi Mengeset Mesin dan Program NC/CNC (M7.15A). Standar kompetensi tersebut, dalam pembelajaran di SMK, dikemas ke dalam satu mata pelajaran yang disebut mata pelajaran CNC. Mata pelajaran CNC adalah mata pelajaran bidang otomasi pada program keahlian Teknik Pemesinan yang harus dikuasai oleh peserta didik. Sesuai dengan focus penelitian, maka Standar kompetensi mata pelajaran CNC yang dipiliah adalah Memprogram Mesin NC/CNC (M7.18A). Standar Kompetensi ini terdiri dari beberapa kompetensi dasar yang harus dicapai, yaitu: 1) Mengenal dasar bagian-bagian program mesin NC/CNC, 2) Menulis dasar program mesin NC/CNC, 3) Lembar penulisan operasi NC/CNC, dan 4) Menguji coba program.

\section{METODE PENELITIAN}

Mengacu pada tujuan penelitian, metode penelitian yang digunakan alam penelitian ini adalah metode eksperimen kuasi, dengan desain penelitian one group pre test-post test, yaitu penelitian yang dilaksanakan pada satu kelas eksperimen tanpa menggunakan kelas kontrol. Eksperimen diawali dengan memberikan pre test (tes awal) untuk mengetahui kemampuan awal peserta didik, kemudian dilaksanakan pembelajaran dengan mengacu pada RPP yang telah didesain (perlakuan). Setelah pembelajaran selesai, selanjutnya dilakukan post test (tes akhir) untuk mengetahui peningkatan penguasaan siswa terhadap kompetensi yang telah diberikan. Desain ini 
dapat digambarkan pada gambar sebagai berikut (Sukmadinata, 2005: 208):

\begin{tabular}{|c|c|c|c|}
\hline Kelas & $\begin{array}{c}\text { Tes } \\
\text { awal }\end{array}$ & $\begin{array}{c}\text { Perlakua } \\
\mathbf{n}\end{array}$ & $\begin{array}{c}\text { Tes } \\
\text { akhir }\end{array}$ \\
\hline Eksperimen & $\mathbf{O}$ & $\mathbf{X}$ & $\mathbf{O}$ \\
\hline
\end{tabular}

Data utama yang diperlukan dalam penelitian ini adalah hasil belajar siswa, baik sebelum proses pembelajaran maupun setelah proses pembelajaran. Sebagai pendukung digunakan juga data tentang judgement RPP yang telah didesain, dan pelaksanaan pembelajaran dengan mengacu pada RPP yang telah didesain. Sumber data dalam penelitian ini adalah guru mata pelajaran CNC, pihak industri dan ahli akademis bidang otomasi, serta peserta didik kelas 3 Program Keahlian Teknik Pemesinan. Sumber data dokumentasi adalah dokumen pembelajaran.

Penelitian ini dilaksanakan dalam beberapa tahapan, yaitu:

1. Penyusunan RPP yang meliputi kegiatan: a) Mendesain perangkat persiapan pembelajaran ( pemetaan kompetensi, pembuatan silabus pembelajaran dan RPP), b) menyusun instrumen penelitian yang meliputi pedoman wawancara, pedoman tes, dan pedoman observasi, dan c) sosialisasi dan wawancara kepada judger untuk judgement perangkat persiapan pembelajaran.

2. Tahap penggunaan RPP dalam pelaksanaan pembelajaran dengan tahapan: a) Tes awal peserta didik, b) observasi pelaksanaan pembelajaran dengan mengacu kepada RPP yang telah didesain ,dan c) Tes akhir peserta didik.

3. Tahap analisis data dan pembahasan.

4. Tahap penyimpulan hasil penelitian.

\section{HASIL DAN PEMBAHASAN}

\section{Deskripsi Data Pre Test,}

Berdasarkan hasil penelitian, diperoleh hasil seperti tergambarkan pada gambar di bawah ini.

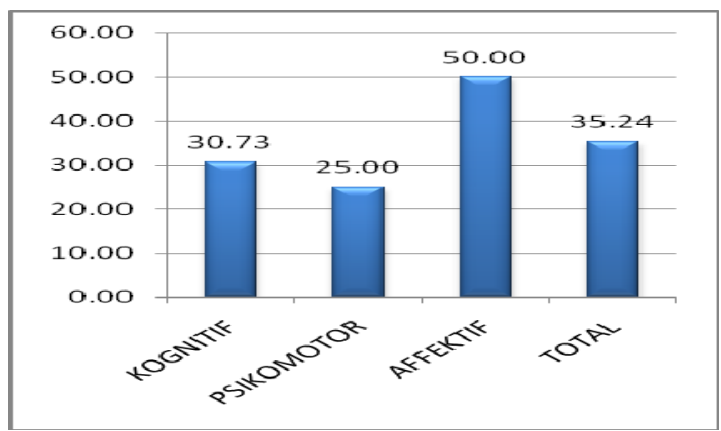

Berdasarkan gambar di atas, diperoleh bahwa rata-rata kemampuan awal siswa pada pembelajaran kompetensi dasar menulis program CNC sebesar 35,24. Rata-rata tersebut berada pada rentang skor minimal 29,33 dan skor maskimal 42,67 dengan simpangan baku 2,97. Dari rentang skor, rata-rata dan simpangan baku tersebut, ada 2 (dua) orang siswa $(6,1 \%)$ yang tergolong memiliki kemampuan awal dalam kategori tinggi, 30 orang siswa (90,9\%) yang tergolong memiliki kemampuan awal dalam kategori sedang, dan 1 (satu) orang siswa (3\%) yang tergolong memiliki kemampuan awal dalam kategori rendah. Adapun ratarata kemampuan awal siswa untuk setiap aspek kompetensi adalah sebagai berikut:

a. Untuk aspek kognitif, rata-rata kemampuan awal siswa sebesar 30,73 yang berada pada rentang 13 sampai 53 dengan simpangan baku 8,91. Dari rentang skor, rata-rata dan simpangan baku tersebut ada 1 (satu) orang siswa (3\%) yang tergolong memiliki kemampuan awal aspek kognitif dalam kategori tinggi, 31 orang siswa (94\%) yang tergolong memiliki kemampuan awal aspek kognitif dalam kategori sedang, dan 1 (satu) orang siswa (3\%) yang tergolong memiliki kemampuan awal kognitif dalam kategori rendah.

b. Untuk aspek psikomotor, rata-rata kemampuan siswa sebesar 25 yang semuanya (100\%) tergolong memiliki kemampuan awal aspek psikomotor dalam kategori sedang.

c. Untuk aspek afektif, rata-rata kemampuan siswa sebesar 50 yang semuanya (100\%) tergolong memiliki 
kemampuan awal aspek apektif dalam kategori sedang.

\section{Deskripsi Data Post Test.}

Berdasarkan hasil penelitian, diperoleh hasil seperti tergambarkan pada gambar berikut.

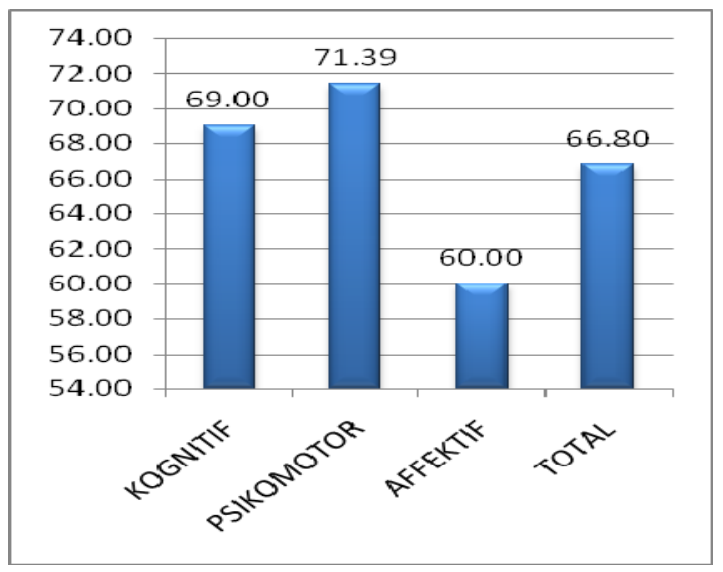

Berdasarkan gambar di atas, diperoleh bahwa rata-rata kemampuan siswa pada pembelajaran kompetensi dasar menulis program CNC setelah digunakan RPP berbasis kompetensi adalah sebesar 66,80. Rata-rata tersebut berada pada rentang skor minimal 58 dan skor maskimal 72 dengan simpangan baku 2,68. Dari rentang skor, rata-rata dan simpangan baku tersebut ada 2 (dua) orang siswa (6,1\%) yang tergolong memiliki kemampuan akhir dalam ketegori tinggi dan 31 orang siswa (93,9\%) yang tergolong memiliki kemampuan akhir dalam kategori sedang, dan tidak ada siswa yang memiliki kemampuan akhir dalam kategori rendah.

Adapun rata-rata kemampuan akhir siswa untuk setiap aspek kompetensi adalah sebagai berikut:

a. Untuk aspek kognitif, rata-rata kemampuan akhir siswa sebesar 69 yang berada pada rentang 53 sampai 80 dengan simpangan baku 4,76. Dari rentang skor, rata-rata dan simpangan baku tersebut ada 2 (dua) orang siswa $(6,1 \%)$ yang tergolong memiliki kemampuan awal aspek kognitif dalam kategori tinggi, 31 orang siswa (93,9\%) yang tergolong memiliki kemampuan awal aspek kognitif dalam kategori sedang, dan tidak ada satupun siswa yang tergolong memiliki kemampuan awal kognitif dalam kategori rendah.

b. Untuk aspek psikomotor, rata-rata kemampuan siswa sebesar 71,39 yang berada pada rentang 61 sampai 76 dengan simpangan baku 3,62. Dari rentang skor, rata-rata dan simpangan baku tersebut tidak ada satu orang siswa pun yang tergolong memiliki kemampuan akhir pada aspek kognitif dalam kategori tinggi, 32 orang siswa (96,9\%) yang tergolong memiliki kemampuan akhir pada aspek kognitif dalam kategori sedang, dan 1 (satu) orang siswa $(3,1 \%)$ yang tergolong memiliki kemampuan akhir pada aspek kognitif dalam kategori rendah.

d. Untuk aspek afektif, rata-rata kemampuan siswa sebesar 60 yang semuanya (100\%) tergolong memiliki kemampuan akhir aspek apektif dalam kategori sedang.

\section{Deskripsi Data $N$-Gain}

$N$-Gain digunakan untuk melihat peningkatan penguasaan siswa terhadap kompetensi menulis program CNC sebelum dan sesudah diimplementasikan RPP berbasis kompetensi. Berdasarkan hasil penelitian diperoleh hasil seperti terlihat dalam gambar berikut.

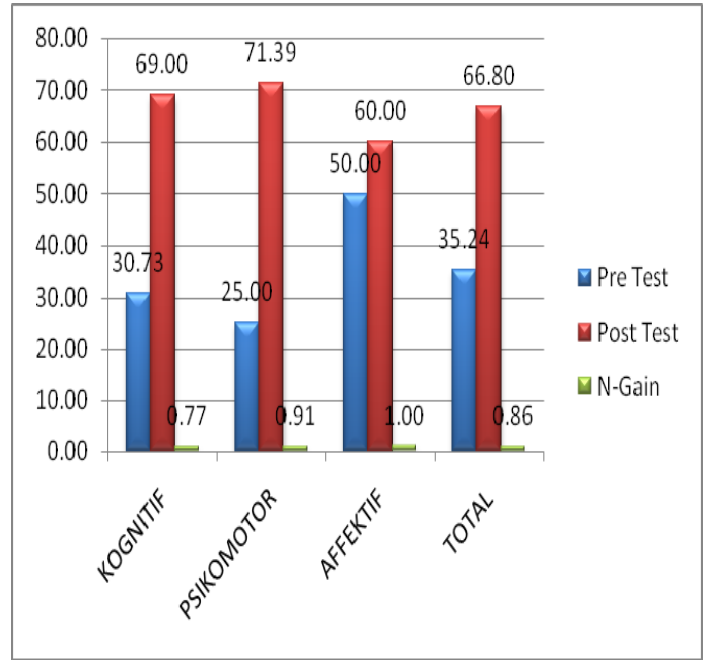

Berdasarkan gambar di atas, terlihat bahwa rata-rata $N$-Gain untuk aspek kognitif adalah 
0.77, dan termasuk pada kategori tinggi, untuk aspek psikomotor sebesar 0.91 dan termasuk pada kategori tinggi, untuk aspek afektif sebesar 1 dan termasuk kategori tinggi, dan secara totalitas rata-rata $\mathrm{N}$-Gain nya adalah sebesar 0.86, juga termasuk kategori tinggi.

\section{PEMBAHASAN}

Berdasarkan hasil penelitian, ternyata penggunaan RPP berbasis kompetensi telah mampu meningkatkan penguasaan siswa SMK terhadap kompetensi menulis program CNC. Peningkatan tersebut terlihat dari $\mathrm{N}$ Gain dan perbedaan nilai rata-rata antara pre test dan post test. Perbedaan rata-rata antara pre test dan post test tersebut, berdasarkan hasil uji t, menunjukkan perbedaan yang signifikan pada tarap kepercayaan 5\%, baik untuk setiap aspek kompetensi maupun secara totalitas. Hal ini terbukti dengan hasil pengujian yang menunjukkan bahwa $t_{\text {hitung }}=$ $10,92>t_{\text {tabel }}=1,671$. Selain itu, berdasarkan data $N$-Gain ternyata semuanya berada pada kategori tinggi baik untuk setiap aspek/ranah (kognitif, afektif, dan psikomotor), maupun secara totalitas. Dengan kata lain, peningkatan penguasaan siswa SMK terhadap kompetensi menulis program CNC masih tergolong pada kategori tinggi, baik secara totalitas maupun untuk masing-masing aspek kompetensi (kognitif, psikomotor, dan afektif). Meskipun peningkatan hasil belajar tersebut termasuk kategori tinggi, tetapi jika dilihat dari rata-rata kemampuan akhir siswa, ternyata masih tergolong pada kategori sedang baik secara totalitas maupun untuk setiap aspek/ranah.

Kondisi tersebut menggambarkan bahwa peranan RPP dalam pelaksanaan pembelajaran sangatlah membantu guru dalam memandu seluruh aktivitas yang harus dilakukannya selama proses pembelajaran. Oleh karena itu, keberadaan RPP hendaknya tidak hanya sebatas kelengkapan dokumen, tatapi harus menjadi bahan acuan atau pedoman bagi guru dalam melaksanakan proses pembelajaran. Berdasarkan prinsipprinsip pembelajaran berbasis kompetensi, dalam menyusun RPP, seorang guru dituntut untuk dapat menterjemahkan prinsip-prinsip tersebut kedalam dokumen rencana pelaksanaan pembelajaran tersebut. Dengan demikian, apa yang akan ditampilkan oleh guru di dalam kelas sudah harus tergambar dalam dokumen RPP yang dikebangkan. Artinya, dokumen RPP tersebut merupakan "panduan" guru yang bersangkutan dalam melaksanakan tugasnya di kelas/tempat praktek.

Meskipun di satu sisi menujukkan adanya peningkatan hasil belajar siswa yang merefleksikan tingkat penguasaan terhadap suatu kompetensi, tetapi di sisi lain masih dipandang belum memuaskan. Hal ini terlihat dengan penguasaan akhir siswa terhadap kompetensi menulis program CNC yang hanya termasuk ke dalam kategori sedang. Idealnya, para siswa tersebut mampu menguasai kompetensi dalam menulis program CNC ini secara optimal atau masuk ke dalam kategori tinggi. Hal ini dimaksudkan agara mereka mampu berkompetisi dengan yang lain di dunia kerja, baik pada tataran lokal, regional, nasional, maupun internasional. Ini dapat difahami, karena mereka merupakan peserta didik pada lembaga pendidikan kejuruan yang memang disiapkan untuk menjadi calon tenaga kerja yang akan mengisi kekosongan jabatan di industri, khususnya industri pemesinan.

Kurang optimalnya para siswa dalam menguasai kompetensi menulis program CNC, tidak terlepas dari beberapa faktor yang mempengaruhinya. Faktor-faktor tersebut secara garis besar dikelompokkan menjadi faktor internal (dari dalam diri siswa) dan faktor eksternal (dari luar diri siswa). Faktor yang berasal dari dalam diri siswa terkait dengan karakteristik yang dimiliki oleh setiap siswa baik fisiologis, maupun psikologi ( intelektif maupun non intelektif). Adapun faktor yang berasal dari luar diri siswa dapat berasal dari guru (kemampuan dalam mengelola pembelajaran), kurikulum, dan sarana prasarana.

Peran guru dalam pembelajaran sangatlah sentral, oleh karena merupakan komponen sistem pendidikan formal yang 
langsung berhubungan dengan peserta didik. Oleh karena itu, guru di tuntut untuk mampu melaksanakan tugas secara professional. Guru yang professional adalah guru yang menguasai empat pilar kompetensi secara utuh, yaitu kompetensi sosial, kompetensi kepribadian, kompetensi pedagogik, dan kompetensi preofessional. Terkait dengan pengelolaan pembelajaran, seorang guru dikatakan professional apabila dia mampu mengelola pembelajaran secara efektif. Jadi seorang guru professional merupakan seorang guru yang efektif. Seorang guru dikatakan efektif dalam mengajar apabila dia memiliki kemampuan yang terkait dengan iklim belajar, strategi manajemen pembelajaran, pemberian umpan balik dan penguatan, dan peningkatan diri dalam kaitan dengan perannya sebagai expert learners, sebagai manager, dan sebagai mediator.

Terkait dengan ketiga peran seperti di atas, khususnya dalam lembaga pendidikan kejuruan seperti SMK, guru dituntut memiliki kompetensi yang lebih tinggi. Dalam mengelola pembelajaran misalnya, tugas dan tanggung jawab guru SMK jauh lebih berat dibanding dengan guru sekolah umum. Oleh karena, guru SMK harus memiliki kemampuan dalam mengelola pembelajaran teori dan pembelajaran praktik secara bersamaan. Hal ini didasarkan pada makna dari pendidikan kejuruan, yaitu suatu pendidikan yang bertugas menyiapkan lulusannya untuk dapat bekerja sesuai dengan bidang keahlian yang dimilikinya, sehingga mereka mampu mengisi kekosongan jabatan yang ada di DUDI.

Mengenai pendidikan kejuruan ini, dalam UUSPN Nomor 20 tahun 2003, penjelasan pasal 15, dijelaskan bahwa pendidikan kejuruan adalah pendidikan yang mempersiapkan peserta didik untuk dapat bekerja dalam bidang keahlian tertentu. Hal ini sejalan dengan pendapat Sukamto (1988:33) yang mengemukakan bahwa: "pendidikan kejuruan adalah pendidikan yang memfokuskan usahanya pada penyelenggaraan program pendidikan dan pelatihan untuk mengembangkan Sumber Daya Manusia (SDM).” Meskipun demikian, bukan berarti bahwa pendidikan kejuruan hanya mendidikan peserta didik dengan sperangkat skill atau kemampuan yang spesifik untuk pekerjaan tertentu saja, karena hal ini biasanya kurang memperhatikan perkembangan peserta didik sebagai suatu totalitas. Ungkapan tersebut dipertegas oleh Sukamto (1988 : 26) yang menjelaskan bahwa: "pendidikan kejuruan merupakan upaya dalam menyediakan stimulus yang berupa pengalaman belajar dan interaksi dengan dunia di luar peserta didik untuk membantu mereka mengembangkan diri dan potensinya." Berdasarkan kedua pendapat tersebut, jelaslah bahwa peserta didik di lembaga pendidikan kejuruan dituntut untuk memiliki tingkat penguasaan yang baik terhadap suatu kompetensi, sebagai bekal bagi dirinya untuk kelak di lapangan.

\section{KESIMPULAN DAN SARAN}

\section{Kesimpulan}

Berdasarkan hasil pengolahan data dan pembahasan, diperoleh beberapa temuan penelitian sebagaiberikut:

a. Tingkat penguasaan siswa terhadap kompetensi menulis program CNC pada aspek kognitif tergolong kategori sedang.

b. Tingkat penguasaan siswa terhadap kompetensi menulis program CNC pada aspek psikomotor tergolong kategori sedang.

c. Tingkat penguasaan siswa terhadap kompetensi menulis program CNC pada aspek afektif tergolong kategori sedang.

Berdasarkan temuan-temuan tersebut, dapat disimpulkan bahwa tingkat penguasaan siswa SMK terhadap kompetensi menulis program CNC pada mata pelajaran CNC masih tergolong pada kategori sedang.

\section{Saran}

Berdasarkan temuan penelitian dan kesimpulan, peneliti mengajukan beberapa saran sebagai berikut:

a. Bagi SMK berkaitan dengan pelaksanaan pembelajaran pada mata kuliah CNC, hendaknya guru difasilitasi untuk mengembangkan dan mengelola proses pembelajaran yang lebih menekankan 
pada pembelajaran yang mengarah pada upaya penguasaan kompetensi siswa secara utuh, diantaranya melalui penyediaan fasilitas pembelajaran yang dibutuhkan.

b. Bagi guru berkaitan dengan pengembangan RPP dan pengembangan pengelolaan pembelajaran, hendaknnya mengembangan RPP yang dapat dijadikan pedoman dalam melaksanakan pembelajaran, serta mengembangkan model-model pembelajaran yang mengarah pada penguasaan kompetensi oleh siswa secara utuh dan melakukan pengawasan lebih otpimal lagi.

c. Bagi siswa hendaknya lebih mengaktifkan diri dalam mengikuti proses pembelajaran dengan cara meningkatkan disiplin dan motivasi, serta lebih mengoptimalkan pemanfaatkan waktu dan fasilitas yang ada.

\section{DAFTAR PUSTAKA}

Anderson and Krathwohl. (2001). A Taxonomy for Learning, Teaching, and Assessing. New York: Addison Wesley Longman, Inc.

Butler, F.C. (1979). Instructional Systems Development for Vocational and Technical Training. Englewood Cliffs, N.J.: Educational Technology Publication.

Calhoun, C.C., Finch, A.V. (1982). Vocational Education: Concepts and Operations ( $2^{\text {nd }}$ ed.). Belmont, California: Wadworth Publishing Company.

Departemen Pendidikan Nasional. (2003). Undang-undang Nomor 20 Tahun 2003 tentang Sistem Pendidikan Nasional. [Online]. Tersedia: http://www.samudrastudio.com/html/FTP/sisdiknas. pdf. [26 Mei 2007]
Ene-Silvia Sarv, (2003). Teachers as developers of general competences in classroom (in Estonia), Paper presented at the European Conference on Educational Research, University of Hamburg, 17-20 September 2003. Tersedia, http://www.leeds.ac.uk/educol/docum ents/00003371.htm

Mulyasa. (2003). Kurikulum Berbasis Kompetensi. Bandung: Remaja Rosda Karya. - (2005). Implementasi Kurikulum 2004. Bandung: Remaja Rosda Karya.

Prisma Sanjaya. (2005). Pola Pembelajaran. [Online]. Tersedia. http://www.prismasanjayasrg.sch.id/index .html. [26 Mei 2007]

Sekolah Menengah Kejuruan Negeri 6 Bandung. (2006). Kurikulum Satuan Tingkat Pendidikan (KTSP). Bandung: Tidak diterbitkan.

Sellin, Burkart. (2002), Scenarios and strategies for vocational education and lifelong learning in Europe. Luxembourg: Office for Official Publications of the European Communities.

Sukamto, (1988), Perencanaan dan pengembangan Kurikulum Pendidikan Teknologi dan Kejuruan, Jakarta : P2LPTK Ditjen Dikti.

Suyanto, (2007), Guru yang professional dan efektif. [Online] Tersedia http://gurutapteng.wordpress.com

Sukmadinata, N.S. (2005). Metode Penelitian Pendidikan. Bandung: Remaja Rosda 